\title{
Human Genetic and Reproductive Technologies: A Muslim's Understanding of the Secular Perspective
}

\author{
Shahid Athar, MD, FACP, FACE \\ Department of Endocrinology and Medicine \\ St. Vincent Hospital and Indiana University School of Medicine \\ Indianapolis, Indiana
}

\begin{abstract}
Physically and intellectually, man is not the same as he was a million years ago. These "improvements" in humans have come from within over a period of time by the process of adaptation, new learning, and out of a need. So, what is the need now for biotechnical intervention? The fine line between what can be done technically and what should be done morally is the reason for the role of biomedical ethics in the area of human genetic technologies. What is the relationship between the individual and society? Whose interests and needs are we, the scientists and physicians, to serve? Where does the government fit in between the needs of the individual patient and duties of his or her physician? Are social justice, human dignity, and human rights to be considered in genetic modification? While it may be appropriate and desirable to seek treatment for a disease such as infertility, we have moved beyond treating infertility to the quest of making a super healthy super human. As a result, are we embarking on a path of ethnic cleansing of humans of lesser abilities? In this paper, such concerns and questions are discussed from a secular perspective.
\end{abstract}

Key words: Human genetics, assisted reproductive technologies, cloning, ethics.

$\mathrm{F}$ or the past several years, I have written and - spoken on medical ethics from a religious (Islamic) perspective.1-4 However, in this paper, I will be discussing human genetics and reproductive technology from a secular perspective. I have chosen to do so as I strongly feel that there is common

Presented at the International Seminar on Human Genetic and Reproductive Technologies in Cairo, Egypt, on February 8, 2006, and organized by the Islamic Organization of Medical Sciences (IOMS) and the Eastern Mediterranean Regional Office (EMRO) of the World Health Organization (WHO).

Correspondence should be directed by email to sathar3624@aol.com ground in medical ethics between the religious and secular camps. My aim is not to promote secularism but for the religious group to understand the secular view. Both groups, in my opinion, support core principles of biomedical ethics, such as autonomy of the patient, beneficence, nonmalfeasance, and distributive justice.

The religious group, whether we like it or not, has taken it upon itself to speak and act on behalf of God $\mathrm{all}_{\text {. }}$. It sees itself as an extension of God's healing powers. It has a self-appointed role of imple menting God's injunctions for the benefit of mankind.

The secular camp, on the other hand, also works toward the goal of protecting human values and human rights. It sees God as a creation of the human 
mind. For this group, this life is the only life. It empowers man to the best of its potential. What is good for man is good for humanity. The ends justify the means.

However, in spite of some commonality, the two groups have very different opinions on the needs of the individual versus the needs of society in the areas of human dignity, human rights, and the role of physicians (scientists). The religious group believes that physicians and scientists are subservient to God alle, while the secular group believes that they are subservient only to the individual.

Thus, in the pursuit of scientific knowledge and its effects on the future of the human race, we are sailing in uncharted seas and have created areas of concern that are still being debated.

In reviewing the current literature on assisted reproductive technologies (ARTs) and biogenetics, some controversies are obvious. Commenting on the relationship between science and morality, Surbone argues that "the role of genetic knowledge is overestimated and may either enhance the control that individuals have on their lives or finalize the decision process of the individual who may feel predisposed to a serious disease." ${ }_{5}$ On the other hand, Cohen feels that "the opposing camps in bioethics about reproductive human cloning are not wholly opposed to each other. In fact, they hold certain beliefs and values which are common concerns and they have reconciled their world views on several issues in human reproductive cloning."' While discussing the respect for the human embryo, GomezLobo $^{7}$ feels that "since they have potential to become adult persons, they are already persons deserving the same rights as adult persons." Reviewing and commenting on creation and sacrificing embryos for stem cells, Devolder feels that "creation and destruction of embryos is at the same plane, i.e. one cannot accept the creation and sacrifice of embryos for infertility but condemn the same for the benefit of injured people."

The controversy about the use of discarded embryos for human research ${ }^{9}$ revolves around determining when an embryo becomes a moral person. According to Ken Hilma, "this happens when brain activity starts. So, it is postulated, that a human being is a human person by nature and a human embryo is a human person by nature and should be treated as such."

On the ethics of human stem cell research, Outka $^{10}$ from Yale and Heineman ${ }^{11}$ have written noteworthy articles. Mahowald 12 argues that "cloning is necessary to preserve bodily integrity or life of an individual." She suggests that scientists and clinicians may respect the negative right to moral integrity with whom they disagree. On the other hand, Lee suggests that "choice of reproductive means is a human right." He recommends that "a balanced approach be adopted to benefit human society while protecting human dignity." He is of the opinion that "a temporary ban on human cloning is appropriate but the ban on relevant scientific research and animal experimentation is inappropriate as it denies the sprit of freedom of scientific inquiry and hinders making the benefits of scientific advancement available to human society as whole."13

Paul Lauritzen writes: "If stem cell research led to therapies that changed the contour of human life, it would unsettle our ethical commitments, including the very notion of a human right, and encourage us to see the entire natural world, the human body along with it as having the status only of material to be manipulated." He quotes C.S. Lewis "... the final stage is come when man by eugenics, by prenatal conditioning and by education and propaganda based on perfect applied psychology, has obtained full control over himself. Human nature will be the last part of nature to surrender to man." He goes on to quote Jonathan Clover: "Human responses are the core of humanity which contrasts with inhumanity." Lauritzen concludes that "morality must be rooted in human needs and values which are rooted in 'human nature' and grounded in human aspirations." 14

Professional scientific societies have stated their positions on stem cell research. The Endocrine Society is of the opinion that stem cell research holds promise for 128 million Americans suffering from diseases such as diabetes mellitus, Alzheimer's disease, Parkinson's disease, spinal cord injury, stroke, muscular dystrophy, Lou Gehrig's disease, heart diseases, lung diseases, kidney diseases, acquired immune deficiency syndrome (AIDS), liver disease, arthritis, anemia, and leukemia. While the ongoing research on adult stem cell is promising, it does not have the same potential for pluripotency as embryonic stem cells. It is for this reason the society 
supports funding for further stem cell research. Its members have witnessed transplantation of human tissues such as kidney, heart, and bone marrow cells and the improved quality of life it has given to many patients. The society supports the collection of stem cells through voluntary donation only, without monetary incentives, and after thorough informed consent. Furthermore, the society agrees with National Academy of Science report, which recommends that biomedical research using nuclear transplantation to produce stem cells be permitted and a ban on reproductive cloning be imposed. ${ }^{15}$

Another controversial topic between religious and secular forces is the current status of nearly 400,000 surplus or unused frozen embryos in the United States. ${ }^{16}$ On one hand, the Republican administration, which is collectively against abortion, is in favor of promoting embryo adoption, while other groups are in favor of donating them for stem cell research. This has opened a "Pandora's box" of ethical and legal concerns. The difference between what can be done and what should be done is the reason for ethics.

Thus, we see that much has been written already and published in this area by many organizations, including the Islamic Organization of Medical Sciences (IOMS) ${ }^{17}$ and the American Society for Reproductive Medicine ${ }^{18-20}$, as well as from the Islamic perspective. ${ }^{21}$

Below are my responses to the questions the IOMS posed to a panel at the International Seminar on Human Genetic and Reproductive Technologies in Cairo, Egypt, on February 8, 2006.

\section{Social Impacts of Genetic and Reproductive Technology: The Secular Perspective}

Question 1: What in the secular tradition is the vision of good society and the relationship between individuals and society? How does it differ from the Western secular liberal vision of a society composed of rational, self-interested and autonomous individuals, which emphasizes the importance of individual freedom? To what extent, are questions of social justice, who benefits and who loses, relevant in clinical consideration in secular society?

Answer: The secular vision of a good society is a society that is based on human rights and human freedom, caring for everyone who lives in that society, irrespective of color, gender, social status, political, or religious affiliation. It emphasizes the impor- tance of individual freedom and choices in the interest of the individual. All programs in this society are geared toward empowering individuals and the community. It sees the practice of religion as a private and a personal matter. Religion in a secular society is allowed, but coercion of others on the basis of religion is not. Social justice is distributive justice and ideally, everyone is an equal loser or beneficiary. Ethics is not morality but a sum of values.

Question 2: How are the genetic and reproductive technologies affecting the relationship between individuals and society? Is it fair to say that they tend to encourage greater emphasis on individuals' inherent characteristics and competition and therefore greater inequality and less social solidarity?

Answer: It is true that in a secular society there is more emphasis on individuals rather than on the society at large. Because society is directed by secular individuals, the society will tend not to implement policies detrimental to the individual. There is a possibility of some inequality, but that is related to availability of resources more than the intent. On the other hand, in a religious or ethnic society, the majority is more beneficiary of the available benefits, while secularists and minorities are treated as second-class citizens in terms of ethical rights.

Question 3: If it is true that selection and design of babies undermines human dignity, does that potentially also undermine human rights?

Answer: Yes, it is true to some extent that designing a baby undermines human dignity. However, it is a matter of choice. If individuals have a right to make the choice, they must live with that choice. While it may be appropriate for a certain couple to want all healthy babies with a specific appearance, it may not be appropriate to want all babies to be of the same sex for social reasons. Human rights will be infringed upon if society declares that all children be born with the same genotype.

Question 4: Is there a philosophical basis within a secular tradition for concerns about social discrimination on the basis of genes, for example, in insurance and employment?

Answer: Social discrimination in employment and health care is prevalent in all societies, secular or not. Women and African Americans receive lower 
salaries and fewer bypass procedures, dialysis treatments, and heart and kidney transplants in the United States compared to Caucasian men. In my opinion, such discrimination will still be seen in secular societies based on the socioeconomic status of the individual but to a lesser extent. A religious society, unless religion is practiced in its purest form, in my opinion, practices greater discrimination.

Question 5: To what extent can arguments about the appropriate use of limited resources be made within the secular tradition?

Answer: In a true secular society, theoretically, because there is no discrimination based on religion or social class, the use of resources will be appropriate and only limited by availability. If a heart or kidney transplant, for example, is needed, it will be on a first come, first serve basis, not on the basis of religion or ability to pay.

Question 6: Are genetic and reproductive technologies leading to a new form of eugenics in which disabled people and others who have less of the abilities that society values are gradually eliminated from society? If so, what is the argument against this?

Answer: This is a very touchy subject. Yes, it is possible to some degree that there will always be survival of the fittest. However, because the secular society, or as a matter of fact, in a true religious society, all individuals will have equal rights, it will not happen. There always will be forces that will advocate for the rights of the disabled. This will include not only the disabled individual but also the unborn. Thus, total elimination or discrimination or ethnic cleansing of the weak and disabled will never happen no matter how oppressive or how fair the establishment is, secular or religious.

In conclusion, I believe the controversy between the religious and secular groups will continue, but I ask both groups to continue to interact and communicate with the each other. They need each other's input and suggestions. I ask that religious scholars keep up with the changing scientific knowledge and technologies. They should not accuse scientists of playing God, as we all try to do the same at times.

We really do not know what the future of stem cell and cloning research hold for humanity. Thus, it will be premature to foretell. As Ted Peters, the prin- cipal investigator of the Center for Theology and the Natural Sciences research project funded by the United States National Institutes of Health (NIH) to study the Human Genome Initiative's ethical and theological implications, pointed out:

If a primitive man had said now I have discovered fire that we can use for cooking and keeping ourselves warm, the holy men would have objected saying that this fire will burn our huts and trees, thus it is bad for humanity. Well, such objections did not prevent the progress of science. ${ }^{22}$

I end by quoting a friend of mine, Dr. Gary Wright, anesthesiologist and chair of medical ethics at the Catholic hospital where I have practiced endocrinology for the last 30 years:

Given a choice, one may prefer to live in a religious society where the religion is practiced in its purest form and the citizens of nonruling religions and secularists are treated with equal human rights and human dignity. However, in the absence of such utopian society at this age, one may accept to live in a secular society holding on to the above the values to the maximum.

\section{Dr. Wright wrote to me:}

The Late Pope John Paul has taught me much about human dignity. Commodifying new biotechnology will be both wonderful as we discover cures for chronic illness and human enhancement and at the same time worrisome. Social hierarchies are the greatest barrier to compassion as they intertwine attitudes of superiority and entitlement. Social hierarchies define access to advantageous biotechnologies. Genetic biotechnologies will provide more opportunities for the privileged to ensure that the advantages they buy will become a permanent part of their bodies and their heirs. Equitable access and true usefulness should be litmus test for new biotechnologies. Compassion too easily gives way to personal profit, unfortunately, a stable part of human nature. ${ }^{23}$ 
On this point both secularists and religious ethicists may agree.

\section{Acknowledgements}

I thank Dr. Robert Cleary, professor emeritus of reproductive endocrinology at Indiana University School of Medicine, and the aforementioned Dr. Wright for their constructive converstations with me on these topics.

\section{References}

1. Athar, S. The Islamic perspective in medical ethics. In Athar, S, editor. Islamic perspectives in medicine. Indianapolis, IN: American Trust Publication; 1994. p. 187-94.

2. Athar S. Health concerns for believers: contemporary issues. Chicago, IL: Kazi Publications; 1995.

3. IMANA.org [homepage on the Internet]. Lombard, IL: Islamic Medical Association of North America; c2002-7. Athar S, Fadel HE, Ahmed WD, et al. Islamic medical ethics: the IMANA perspective. [updated 2005 May 15; cited 2007 Apr 2]. Available from: http://data.memberclicks.com/site/imana/IMANAE thicsPaperPart1.pdf.

4. Athar S. End of life issues: an interfaith and Islamic perspective. Third Qatar International Medical Congress; 2005 Nov 12; Doha, Qatar.

5. Surbone A. Genetic medicine: the balance between science and morality. Ann Oncol. 2004;15 Suppl 1:I60I64. Available

from:

http://annonc.oxfordjournals.org/cgi/reprint/15/s uppl_1/i60.

6. Cohen $\mathrm{CB}$. The ethics of human reproductive cloning: when world views collide. Account Res. 2004 Jul-Dec;11(3-4):183-99.

7. Gomez-Lobo A. On potentiality and respect for embryos: a reply to Mary Mahowald. Theor Med Bioeth. 2005;26(2):105-10; discussion 111-3.

8. Devolder K. Creating and sacrificing embryos for stem cells. J Med Ethics. 2005 Jun;31(6):366-70.

9. Devolder K. Human embryonic stem cell research: why the discarded-created-distinction cannot be based on the potentiality argument. Bioethics. 2005 Apr;19(2):167-86.

10. Outka G. The ethics of human stem cell research. Kennedy Inst Ethics J. 2002 Jun;12(2):175-213.

11. Heinemann T, Honnefelder L. Bioethics. 2002 Nov;16(6):530-43.

12. Mahowald MB. Self-preservation: an argument for therapeutic cloning, and a strategy for fostering respect for moral integrity. Am J Bioeth. 2004 Spring;4(2):56-66.

13. Lee $\mathrm{M}$. The inadequacies of absolute prohibition of reproductive cloning. J Law Med. 2004 Feb;11(3):351-72.

14. Lauritzen P. Stem Cells, biotechnology, and human rights: implications for a posthuman future. Hastings Center Report. 2005;35(2):25-33.

15. Stem cell research: The Endocrine Society's position. Endocrine News. 2005;30(9):12-4. Available from: http://www.endosociety.org/news/endocrine_news/2005/upload/FI NAL\%20Dec\%20EN\%202005.pdf.

16. Crockin S. Embryo wars. Boston Globe. Dec. 4, 2005.

17. Islam-SET.com [homepage on the Internet]. AlSulaybikhāt, Al-Kuwait: Islamic Organization for Medical Sciences. [Cited 2007 Apr 9]. Available from http://www.islamset.com/ioms/cairo2006/index.ht $\mathrm{ml}$.

18. The Ethics Committee of the American Society for Reproductive Medicine. Disposition of abandoned embryos. Fertil Steril. 2004;82(supp 1):S253. Available

from: http://www.asrm.org/Media/Ethics/abandonedembryos.pdf.

19. The Ethics Committee of the American Society for Reproductive Medicine. Informed consent and the use of gametes and embryos for research. Fertil Steril. 1997;68:780-1. Available from: http://www.asrm.org/Media/Ethics/informedconsent.pdf.

20. The Ethics Committee of the American Society for Reproductive Medicine. Donating spare embryos for embryonic stem-cell research. Fertil Steril. 2002;78:957-60. Available from: http://www.asrm.org/Media/Ethics/donatingspare.pdf.

21. Fadel HE. Prospects and ethics of stem cell research: an Islamic perspective. J Islam Med Assn. 2007;39:73-83.

22. Peters T. Playing God? Genetic Determinism and Human Freedom. New York and London: Routledge; 1997.

23. Wright G. DO, Anesthesiologist and Ethicist, St. Vincent Hospital, Indianapolis, (personal communication). 